\title{
Contemporary French Poetics, edited by Michael Bishop and Christopher Elson
}

\section{Elisa Bricco}

\section{(2) OpenEdition}

\section{Journals}

\section{Edizione digitale}

URL: https://journals.openedition.org/studifrancesi/41242

DOI: 10.4000/studifrancesi.41242

ISSN: 2421-5856

\section{Editore}

Rosenberg \& Sellier

\section{Edizione cartacea}

Data di pubblicazione: 1 juillet 2004

Paginazione: 223

ISSN: 0039-2944

\section{Notizia bibliografica digitale}

Elisa Bricco, «Contemporary French Poetics, edited by Michael Bishop and Christopher Elson», Studi Francesi [Online], 142 (XLVIII | I) | 2004, online dal 30 novembre 2015, consultato il 09 septembre 2021. URL: http://journals.openedition.org/studifrancesi/41242 ; DOI: https://doi.org/10.4000/studifrancesi. 41242

Questo documento è stato generato automaticamente il 9 septembre 2021.

\section{cc) (ㅇ) $\ominus$}

Studi Francesi è distribuita con Licenza Creative Commons Attribuzione - Non commerciale - Non opere derivate 4.0 Internazionale. 


\title{
Contemporary French Poetics, edited by Michael Bishop and Christopher Elson
}

\author{
Elisa Bricco
}

\section{NOTIZIA}

Contemporary French Poetics, edited by Michael Bishop and Christopher Elson, Rodopi, Amsterbam-New York, 2002, pp.215.

1 Le grandi figure della poesia francese e francofona contemporanea - Bonnefoy, Du Bouchet, Stétié, Deguy, Noël, Chedid, Pleynet, Des Forêts, Dupin - trovano spazio nel presente volume accanto ad autori emergenti, la generazione più giovane di cui fanno parte personalità molto diverse come Pinson, Leclair, Bancquart, ÉEmaz, Maulpoix, Després, Morency, Zins, Lapierre, Nys-Masure, Herlin, Grangaud, Alfiéri, Chrétien, Di Manno.

2 I ventitre saggi proposti sono stati in parte presentati a un convegno svoltosi nel settembre 1998 all'Università di Dalhousie; l'insieme propone una visione ampia e al tempo stesso approfondita della produzione poetica contemporanea. 